\section{Food Insecurity within Low-income Families and Supplemental Third Meal Program for School-aged Children}

Received: August 01, 2016; Accepted: December 07, 2016; Published: December 13, 2016

Food insecurity amongst low-income families has become a prevalent issue in the United States over recent years. At the end of 2014 , a reported 46.7 million Americans were in poverty and 15.5 million (21.1\%) children under the age of 18 suffering from food insecurity [1]. A single mother of three earning twenty-six thousand dollars annually often decides to pay a reoccurring household bill, rather than put food on the table for a week. In 2013, 34.4\% of American women reported food insecurity [2]. In direct correlation, children who live in food-insecure households are less likely to reach their full educational potential if they are malnourished, experience lower math scores, and decreased cognitive functioning with breakfast removed [3]. To improve educational performance, Congress established the pilot breakfast program in 1966, which became a permanent entitlement in 1975 [4]. Providing breakfast at school improves concentration, alertness, and memory that translate into a better vocabulary with improved test scores. Added assistance such as the Supplemental Nutrition Assistance Program (SNAP), lifted over 5 million Americans out of poverty in 2012 [5], and statistics show that a family which participates in the program for six months, will decrease food insecurity by $10 \%$. In spite of both food assistance programs mentioned, an additional third meal program for school-aged children would be a permanent fix for parents that are contributing to the workforce but earn less than the U.S. median household income of $\$ 52,250$ per year [6]. Introducing new aid programs will evidently target taxpayers. The average SNAP recipient receives $\$ 133$ per month, which totals $\$ 5.5$ billion in government spending each month, and food subsidy programs will cost $\$ 107$ billion in 2016 and account for more than two-thirds of the department's budget, tax additions to those gouty numbers would not be received well [7].

\author{
William Crenshaw \\ USAF Public Health Services, Kaplan \\ University, Davenport, lowa
}

\begin{abstract}
Corresponding author:
William Crenshaw Jr
\end{abstract}

\section{willcnutrition@yahoo.com}

\begin{abstract}
USAF Public Health Services, Kaplan University, Davenport, lowa.
\end{abstract}

Tel: $210-730-0709$

\begin{abstract}
Citation: Crenshaw W. Food Insecurity within Low-income Families and Supplemental Third Meal Program for School-aged Children. J Clin Nutr Diet. 2016, 2:4.
\end{abstract}

However, the 1976 Tax Reform Act (Section 2135) allows business taxpayers that regularly make charitable donations, receive income tax deductions. The Act authorizes donating businesses to determine the "fair market value" of the gift, as long as the monies don't exceed two times the cost of the companies donated inventory [8]. Reintroducing the Tax Reform Act to provide a supplemental dinner meal for children after school, would present a more lucrative plan of action to all businesses alike, and assist in lowering the rates of malnourished children.

In conclusion, shifting the taxpayers focus on every child being afforded three meals a day by implementing food donation program is a significant step in reducing childhood obesity. This forward thinking approach will educate our youth on the importance of healthy foods, which will continue throughout adulthood. 


\section{References}

1 United States Census Bureau (2015) Income, Poverty and Health Insurance Coverage in the United States: 2014.

2 Feeding America (2015) Hunger and Poverty Facts and Statistics.

3 Food Research and Action Center (FRAC) (2014) Breakfast for Learning, Skipping Breakfast and Experiencing Hunger Impair Children's Ability to Learn. Eating Breakfast at School Helps Improve Children's Academic Performance.

4 Food Research and Action Center (FRAC) (2015) School Breakfast Program, Many More Low-Income Children Starting the Day with
School Breakfast, Find New Reports from the Food Research and Action Center.

5 United States Department of Agriculture (USDA) (2014) Food and Nutrition Service, Supplemental Nutrition Assistance Program (SNAP).

6 Noss A (2014) U.S. Department of Commerce Economics and Statistics Administration, U.S. Census Bureau, American Community Survey Briefs, Household Income: 2013.

7 Elisabeth M (2011) TownHall Magazine, Tipsheet, How Much Are Food Stamps Costing Taxpayers?

8 Feeding America (2016) Tax Benefits for your Company, Allowable Deductions for Charitable Donations of Ordinary Income Property. 